\title{
Effectiveness of storage as a point-of-use means of improving the bacteriological quality of drinking water
}

\author{
F. AYOADE ${ }^{1 *}$, S.O. FAYEMI ${ }^{1}$, G.G. DARAMOLA ${ }^{2}$, A. OSHO ${ }^{1}$, N.E. OYEJIDE ${ }^{1}$, \\ S.A. ADENODI ${ }^{1}$ and K.O. ANAZODO ${ }^{1}$ \\ ${ }^{I}$ Department of Biological Sciences, College of Natural Sciences, Redeemer's University P.O. Box 812, \\ Redemption Camp Post Office, KM 46, Lagos-Ibadan Expressway, Redemption Camp, Ogun State, Nigeria. \\ ${ }^{2}$ Department of Chemical Sciences, College of Natural Sciences, Redeemer's University P.O. Box 812, \\ Redemption Camp Post Office, KM 46, Lagos-Ibadan Expressway, Redemption Camp, Ogun State, Nigeria. \\ *Corresponding author, E-mail: fayoade22@gmail.com
}

\begin{abstract}
The evaluation of the effectiveness of storage as a point-of-use means for improving the bacteriological quality of drinking water was carried out using a completely randomized block design. Total plate and total coliform counts were enumerated for day 0 -10 samples using Nutrient Agar (NA) and multiple tube techniques respectively. Physicochemical analyses of water samples were carried out using standard procedures including titrimetric methods. Ten bacteria species including Escherichia coli, Bacillus cereus, Citrobacter freundil, Salmonella typhymurium, Pseudomonas aeruginosa, Staphylococcus aureus, Klebsiella pneumoniae, Arizona spp., Proteus vulgaris, Enterobacter aerogenes were isolated from water samples obtained from borehole, well and sachet water samples in the study area. For day zero samples, it was found that the total bacteria counts ranged from $1.01 \times 10^{2}$ to $4.38 \times 10^{2} \mathrm{CFU} / \mathrm{mL}$ for borehole, $0.57 \times 10^{2}$ to $2.13 \times 10^{2} \mathrm{CFU} / \mathrm{mL}$ for well and $0.54 \times 10^{2}$ to $0.92 \times 10^{2} \mathrm{CFU} / \mathrm{mL}$ for sachet water. A significant reduction in bacteria load was recorded for all samples from day 2 to day 7 when the water samples were monitored over a period of ten days. The results reveal that water storage for 2-7 days is a viable point-of-use method of household level drinking water disinfection. (c) 2013 International Formulae Group. All rights reserved.
\end{abstract}

Keywords: Nigerian Institute of Standards, Coliforms, water storage, E. coli.

\section{INTRODUCTION}

In order of importance to life, water is second only to air. Water is so crucial to most metabolic processes in the human body that death results within three to seven days without water (Tortora and Derrickson, 2007). The WHO estimates that over 1 billion people worldwide lack access to safe water (WHO, 2004, 2006). The most challenging constraints to the universal provision of piped borne water are economic and political. This means that many of the poorest people on earth are saddled with the responsibility of collecting, treating (at the point of use) and storing their drinking water by themselves at the household level (Sobsey, 2002). Lack of access to safe drinking water is known to increase the risk of contracting diseases such as diarrhoea, cholera, typhoid, hepatitis $\mathrm{A}$ and amoebic dysentery (WHO, 2006). Reports show that 
every year 4 billion cases of diarrhoea result in 2.2 million deaths in children under 5 years old, the elderly and immune-compromised individuals, particularly in less developed countries (WHO/UNICEF, 2000).

While recent reports indicate a decrease in fatalities caused by water-borne epidemics in Asia, the fatality rate in Africa remains the same. For example, Adikari and Yoshitani (2009) reported a 58\% and 28\% total fatality in Africa and Asia respectively during the period from 1980 to 2006 even though the number of water-related disasters such as flood and tsunami were higher in Asia than in Africa. Natural disasters such as flood and tsunamis are known to exacerbate the impact of water-borne epidemics. These kinds of reports reveal the lack of commitment to developing adequate infrastructures required to provide access to safe drinking water in Africa. Serious shortages in the quality and quantity of water supply in Nigeria are well documented (Fragio, 2005; Dada, 2009; Jimoh and Wojuola, 2009). These shortages are due to increased population growth, urbanization, climate change and existing un-sustainability factors among other risks associated with conventional urban water management especially in developing countries (Khatri and Vairavamoorthy, 2007).

The Nigerian government has set up such agencies as the Federal Environmental Protection Agency (FEPA) and the National Agency for Food and Drug Administration Control (NAFDAC) mandated to protect, enforce, restore and set the water quality standards in Nigeria. However, due to the limited success of these agencies to fulfil their mandate, the public relies solely on private wells, boreholes, stored rain water, water vendors and more recently sachet water for drinking (Egwari and Aboaba, 2002; Dada, 2009). In most Nigerian cities and towns pipeborne water is either non-existent or at best fraught with epileptic supply. In Lagos, Nigeria for example, a city of about 12 million people, the public water covers only about $35 \%$ of the population while $65 \%$ of the population rely on other sources such as private wells, boreholes and water vendors. This situation is further worsened by the fact that Lagos like other Nigerian urban communities does not have any central wastewater collection system, while less than $12 \%$ of households have a working waterborne system (World Bank, 2000). The implications of these statistics to the risk of water-borne epidemics are self-evident.

Water borne outbreaks of enteric diseases is known to be most severe in children under 5 years of age manifesting as acute diarrhoea and often requiring hospitalization. In adults, diarrhoea episodes are often less severe, and resolves without serious medical care. In Nigeria, it is estimated that 315,000 mortalities of children occur annually due to diarrhoeal diseases (Federal Ministry of Health of Nigeria, 1991). More recent studies show that the situation remains unabated as sporadic outbreaks of cholera has been reported in many parts of Nigeria. These outbreaks even though not caused by a single common source; contamination of drinking water constitutes the most easily identifiable outbreak-specific vehicle.

The Red Cross and Crescent Societies (2011) recently reported about 1668 cases of cholera outbreak caused by Shigella dysenteriae type 1 and Vibrio cholera with 43 deaths between the last week of June 2011 and $8^{\text {th }}$ of July, 2011. Studies have shown that bacteria remain the most important causal agent of enteric diseases in Nigeria. Other causal organisms are viruses, protozoa and helminths (Alabi et al., 1998; Egwari and Aboaba, 2002; Raji and Ibrahim, 2011).

The World Health Organization guidelines for bacteriological water quality recommends that all water intended for drinking should contain no coliform organism in any $100 \mathrm{ml}$ sample taken and should be free 
from all hazardous materials as well as being tasteless (WHO, 1995). However, in various parts of Nigeria, data show that the microbial load of drinking water falls out of the margin tolerated by WHO guidelines (Olowe et al., 2005; Onifade and Ilori, 2008; Onweluzo and Akuagbaezie, 2010). On the other hand, erratic supply of piped water has made water storage a necessity in most Nigerian communities. Apart from making up for water shortage, water storage serves another important purpose of reducing the microbial load of drinking water from untreated sources such as well, borehole and from treated sources such as sachet.

Sachet water refers to treated water sold in 50-60 mL polythene sachets under license from the National Agency for Food and Drug Administration Control (NAFDAC). Research has shown that even though regarded as treated, when sachet water samples were examined for the presence of coliforms; 20-90\% incidence of pathogenic bacteria have been reported in some cases (Dada, 2009; Edema et al., 2011). This kind of reports is indicative of non-compliance of manufacturers to NAFDAC and other governmental agencies' guidelines aimed at maintaining the WHO standards for the quality of drinking water.

New strategies are emerging worldwide in order to tackle the spread of water borne diseases at the household level. Referred to as Household Water Treatment (HWT) or Point Of Use technologies (POU), these methods are aimed at reducing exposure to waterborne pathogenic microbes at the household level (Sobsey, 2002; Clasen et al., 2007). These methods include storing water for a few days to reduce microbiological load before drinking, solar disinfection whereby drinking water stored in transparent polythene bottles is exposed to the infra red rays of direct sunshine for 6 or more hours a day to reduce bacterial load, use of filters or a combination of these methods.
Many reports have pointed out the importance of a few days of indoor storage in improving the physical and microbiological quality of water. The duration of storage is also known to affect the microbiological quality of stored ground water (Olayemi et al., 2005; Eniola et al., 2006). Storage acts in three ways; sedimentation, equalization and devitalisation (Graham et al., 1984). Moreover, exposure to light is a well known effective means of microbial control; the fact that even visible light, when present in sufficient intensity can damage or kill microbial cells is well established (Prescott et al., 1999).

Pipe borne water is not available in the 3 urban communities of the Obafemi-Owode Local Government of Ogun State, Nigeria covered by the present work. As a result, this population relies solely on well, borehole and sachet water for drinking purposes. Other drinking water sources (although to a minimal extent) that may be found in this area include stored rain water and bottled treated water. These factors make the present area a good choice for studies in drinking water quality in rural Nigeria. The present work is aimed at using the data obtained from this study as a model for determining if water storage is a HWT/ POU option for improving the bacteriological quality of drinking water in rural Nigeria. In assessing the effectiveness of storage as a means of improving the bacteriological quality of drinking water in the study area, the total heterotrophic bacteria count and the total coliform count as well as some physicochemical parameters were examined over a period of 10 (ten) days.

\section{MATERIALS AND METHODS \\ Study site}

This study was carried out in 3 urban communities namely Mowe ( $\mathrm{N} 06^{\circ} 48.220^{\prime} \mathrm{E}$ $003^{\circ}$ 26. 167'), Imendu-Nla (N06 ${ }^{\circ}$ 48. 241 $\left.\mathrm{E} 003^{\circ} 26.303^{\prime}\right)$ and Loburo (N $06^{\circ} 49.240^{\prime} \mathrm{E}$ $003^{\circ}$ 27. 033') communities in Obafemi 
Owode Local Government, Ogun State, Nigeria between January and March, 2011.

\section{Collection of samples}

Samples of bore-hole tank, well, and sachet water were collected at different locations in Ogun State. Bore-hole water collected at three different locations was designated B1, B2, and B3. Well water also collected at three different locations was designated W1, W2, and W3. The sachet water samples were purchased based on popularity at three different locations and were designated S1, S2, S3 and S4. Samples were taken to the laboratory and labeled accordingly. Analyses were carried out within few hours after sampling. All the water samples were poured into and stored in labeled sterile plastic taper bowls according to standard methods (Radojevic and Bushkin, 2006).

\section{Physical examination}

Visual examination of features external to the water itself such as the label and presence of certification number and other product information of the sachet water samples were noted. Specific odour and appearance, and presence of extraneous materials and floating particles were also noted.

\section{Physicochemical analytical techniques}

Physicochemical analyses of the drinking water samples were carried out according to standard procedures described by Ademoroti (1996) and Radojevic and Bushkin (2006). Temperature and $\mathrm{pH}$ measurements were conducted immediately after collection of the samples. $\mathrm{pH}$ measurements were conducted at $25 \pm 1{ }^{\circ} \mathrm{C}$ using model $3505 \mathrm{pH}$ meter (Jenway, Ltd, U.K). The $\mathrm{pH}$ meter and electrodes were calibrated with buffer solutions of $\mathrm{pH} \quad 7$ and $\mathrm{pH} 4$ for $\mathrm{pH}$ determinations. Conductivity was carried out using model 960 conductivity meter (Schott,
Ltd, Germany). This was calibrated with standard potassium chloride solution and the results presented in $\mu \mathrm{S} \mathrm{cm}^{-1}$.

Hardness of drinking water samples were determined using direct titration with ethylene-diamine-tetra-acetic acid, EDTA $(0.01 \mathrm{M})$. This was standardized against standard calcium or magnesium solution. 100 $\mathrm{mL}$ of water sample was measured. $1 \mathrm{~mL}$ of buffer was added proportionally with Eriochrome Black-T indicator and then titrated with the EDTA solution slowly from a micro-burette. The change from red colour to blue colour showed the end point.

Chloride ions were also determined using titrimetric method. The water samples, $50 \mathrm{~mL}$ each were placed in a $100 \mathrm{~mL}$ conical flask and made up to the mark with distilled water, $0.1 \mathrm{~mL}$ of $\mathrm{K}_{2} \mathrm{CrO}_{4}$ was added and titrated against $0.0282 \quad \mathrm{M} \quad \mathrm{AgNO}_{3}$. All physicochemical tests were conducted within a few hours of obtaining the water samples and also at the end of the 10 days of storage.

\section{Bacteriological analysis}

Total heterotrophic bacteria count of the drinking water samples was determined using pour plate method. The plates were inoculated aerobically at $37{ }^{\circ} \mathrm{C}$ for 24 hours. The total coliform bacteria were determined using the multiple tube fermentation tests and the calculated coliform density computed by the Most Probable Number (MPN) procedures (APHA, 1998). All measurements of parameters were made in triplicates. Results obtained were statistically analyzed using Analyse-it ${ }^{\circledR}$ v. 2.20, statistical software for Microsoft Excel. Variations were considered significant at $\mathrm{p} \leq 0.05$.

\section{RESULTS}

\section{Untreated water sources}

Physical examination of the untreated water samples from boreholes and wells used in the present study revealed that none of the well water samples met the WHO standards 
for physical appearance. The well water samples were turbid and/ or with odour, unlike the samples from the borehole that were colourless, odourless and with no particles as recommended by the WHO (Table 1).

Physicochemical analysis of the water samples from boreholes and wells revealed extremely low ionic values for $\mathrm{Ca}^{2+}, \mathrm{Mg}^{2+}$ and $\mathrm{Cl}^{-}$. Conductivity values of the untreated water samples ranged from $126.45-345.00 \mu \mathrm{S} \mathrm{cm}^{-1}$. By the end of the evaluation period of ten days, the amount of $\mathrm{Ca}^{2+}$ and $\mathrm{Mg}^{2+}$ ions increased greatly for both the well and borehole water samples. The $\mathrm{Cl}^{-}$amounts for all untreated water samples on the other hand reduced drastically when re-evaluated after ten days of storage (Table 2).

Moreover, the total bacterial counts for well water samples were found to range from $7.8 \times 10^{1}$ to $7.7 \times 10^{2}$ for well water and $9.8 \times$ $10^{1}$ to $4.9 \times 10^{2}$ for borehole water samples. The bacterial counts typically increased from a base amount within hours of sample collection, reaching its peak by Day 2 of the evaluation then reducing gradually until the tenth day for all the untreated water samples. The greatest reduction in bacterial count was recorded for the Day 2-4 samples regardless of whether the samples were drawn from borehole or well sources (Table 3). Moreover, a significant reduction in bacteria load of the water samples which generally tapered off approaching the tenth day when the observations were terminated is also shown in Table 3.

The well water samples generally exhibited the highest total bacteria count, when compared with other water sample sources. However, there were no differences in the total bacteria count for borehole and well water samples in some cases (Table 3).

The coliform count ranged from 7 to $180 \mathrm{MPN}$ per $100 \mathrm{~mL}$ for borehole water samples while ranging from 5 to $180 \mathrm{MPN}$ per $100 \mathrm{~mL}$ for well water samples. In all cases except for borehole water from location 2 and well water from location 3 where a dramatic reduction in coliform count from 180 to $<10$ MPN values were recorded, all untreated water samples displayed total coliform counts in the 160 to $180 \mathrm{MPN}$ per $100 \mathrm{~mL}$ range throughout the duration of the experiment (Table 3).

A total of ten bacterial species: Escherichia coli, Bacillus cereus, Citrobacter freundil, Salmonella typhymurium, Pseudomonas aeruginosa, Staphylococcus aureus, Klebsiella pneumoniae, Arizona spp., Proteus vulgaris, Enterobacter aerogenes were isolated; their distribution among the samples are shown in Table 3. Water samples from the borehole located at Imedu Nla was found to contain 9 out of the 10 organisms isolated; an average of 5 organisms was isolated from other sample sources (Table 4).

\section{Treated water sources}

Table 5 shows a record of the results of the physical examination of the sachet water samples. Other than displaying the manufacturer's name, address and NAFDAC number, none of the brands showed other necessary information such as batch number, date of manufacture and best before date (Table 5).

Conductivity values of the sachet water samples ranged from 76.05- $181.20 \mu \mathrm{S} \mathrm{cm}^{-1}$ (Table 2).

Moreover, the total bacterial counts for sachet water samples were found to range from $5.1 \times 10^{1}$ to $4.5 \times 10^{2}$. The bacterial counts typically increased from a base amount within hours of sample collection, reaching its peak by Day 2 of the evaluation then reducing gradually until the tenth day when the experiment was terminated. The greatest reduction in bacterial count was recorded for the Day 2-4 samples (Table 3). The percent reduction in bacteria load of the water samples generally tapered off approaching the tenth day when the observations were terminated. 
There were no differences in the total bacteria count among the different sachet water brands (Table 3).

Even though the coliform count recorded for the sachet water brands was significantly lower than those for the untreated water samples, all the sachet water samples still failed to meet the zero tolerance levels stipulated by NAFDAC for the presence of coliforms in treated water. The coliform count ranged from 0 to $18 \mathrm{MPN}$ per $100 \mathrm{~mL}$. In all cases the coliform count was zero when evaluated within hours of purchase (Day 0) but increased to $18 \mathrm{MPN}$ per $100 \mathrm{~mL}$ for all the brands until the experiment was terminated on the tenth day of storage (Table 3).

Out of a total of ten bacterial species isolated from all the water samples, an average of 5 organisms was isolated from the sachet water samples (Table 5). Even though $E$. coli was not found in any of the sachet water samples, Salmonella typhymurium was isolated from one of the brands evaluated. Staphylococcus aureus was isolated from 2 of the brands of sachet water while Proteus vulgaris was isolated from all the water samples tested (Table 4).

Table 1: Results of physical examination of water samples.

\begin{tabular}{lccc}
\hline Water Source & Colour/ Turbidity & Odour & Particles \\
\hline B1 & Colourless & Odourless & None \\
B2 & Colourless & Odourless & None \\
W1 & Slightly turbid & Slight odour & Few particles \\
W2 & Colourless & Odourless & Few particles \\
W3 & Slightly turbid & Slight odour & Suspended solids \\
S1 & Colourless & Odourless & None \\
S2 & Colourless & Odourless & None \\
S3 & Colourless & Odourless & None \\
S4 & Colourless & Odourless & None \\
\hline B1 = borehole water samples from Imedu Nla; B2 $=$ borehole water samples from Mowe & \\
W1 = well water samples from Imedu Nla; W2 $=$ Well water samples from Mowe & \\
W3 = well water samples from Loburo; S1 = sachet water brand no. 1 & \\
S2 = sachet water brand no. 2; S3 = sachet water brand no. 3; S4 = sachet water brand no. 4
\end{tabular}

Table 2: Results of physical examination for labelling compliance of sachet water samples.

\begin{tabular}{|c|c|c|c|c|c|c|}
\hline Samples & $\begin{array}{c}\text { NAFDAC } \\
\text { number }\end{array}$ & $\begin{array}{c}\text { Best } \\
\text { before } \\
\text { date }\end{array}$ & $\begin{array}{c}\text { Manufacturing } \\
\text { date }\end{array}$ & $\begin{array}{l}\text { Nutritional } \\
\text { information }\end{array}$ & $\begin{array}{c}\text { Batch } \\
\text { number }\end{array}$ & $\begin{array}{c}\text { Producer's } \\
\text { name \& } \\
\text { address }\end{array}$ \\
\hline S1 & + & - & - & - & - & + \\
\hline $\mathrm{S} 2$ & + & - & - & - & - & + \\
\hline S3 & + & - & - & - & - & + \\
\hline $\mathrm{S} 4$ & + & - & - & - & - & + \\
\hline $\begin{array}{l}\mathrm{S} 1= \\
\mathrm{S} 2= \\
\mathrm{S} 3= \\
\mathrm{S} 4= \\
+: \mathrm{Di}\end{array}$ & $\begin{array}{l}\text { et water brand } n \\
\text { et water brand } n \\
\text { et water brand } n \\
\text { et water brand } n\end{array}$ & . & yed on sample label & & & \\
\hline
\end{tabular}


Table 3: Mean Population of Bacteria in Water samples when examined over ten days of storage.

\begin{tabular}{|c|c|c|c|c|c|}
\hline \multirow{2}{*}{ SAMPLES } & \multicolumn{5}{|c|}{ DAYS OF STORAGE (CFU/MPN) } \\
\hline & $\mathbf{0}$ & 2 & 4 & 7 & 10 \\
\hline Location $B 1^{\text {ace }}$ & $3.74 \times 10^{2}\left(180^{+}\right)$ & $4.90 \times 10^{2}\left(180^{+}\right)$ & $3.25 \times 10^{2}\left(180^{+}\right)$ & $3.5 \times 10^{2}\left(180^{+}\right)$ & $3.0 \times 10^{2}\left(180^{+}\right)$ \\
\hline Location $B 2^{\text {be }}$ & $0.98 \times 10^{2}\left(160^{+}\right)$ & $7.50 \times 10^{2}\left(180^{+}\right)$ & $3.65 \times 10^{2}\left(180^{+}\right)$ & $3.4 \times 10^{2}\left(180^{+}\right)$ & $2.75 \times 10^{2}(7)$ \\
\hline Location $W 1^{\mathrm{bc}}$ & $1.51 \times 10^{2}\left(160^{+}\right)$ & $7.70 \times 10^{2}\left(180^{+}\right)$ & $3.9 \times 10^{2}\left(180^{+}\right)$ & $3.85 \times 10^{2}\left(180^{+}\right)$ & $3.10 \times 10^{2}\left(180^{+}\right)$ \\
\hline Location $W 2^{\text {ace }}$ & $0.78 \times 10^{2}\left(160^{+}\right)$ & $7.40 \times 10^{2}\left(180^{+}\right)$ & $2.9 \times 10^{2}\left(180^{+}\right)$ & $2.65 \times 10^{2}\left(180^{+}\right)$ & $2.10 \times 10^{2}\left(180^{+}\right)$ \\
\hline Location $W 3^{\text {ade }}$ & $1.65 \times 10^{2}\left(160^{+}\right)$ & $6.05 \times 10^{2}\left(180^{+}\right)$ & $2.45 \times 10^{2}\left(180^{+}\right)$ & $2.55 \times 10^{2}\left(180^{+}\right)$ & $2.05 \times 10^{2}(5)$ \\
\hline Sachet $1^{\mathrm{a}}$ & $0.81 \times 10^{2}(0)$ & $4.45 \times 10^{2}\left(18^{+}\right)$ & $2.9 \times 10^{2}\left(18^{+}\right)$ & $2.40 \times 10^{2}\left(18^{+}\right)$ & $1.25 \times 10^{2}\left(18^{+}\right)$ \\
\hline Sachet $2^{\mathrm{a}}$ & $0.59 \times 10^{2}(0)$ & $4.00 \times 10^{2}\left(18^{+}\right)$ & $2.35 \times 10^{2}\left(18^{+}\right)$ & $1.95 \times 10^{2}\left(18^{+}\right)$ & $1.65 \times 10^{2}\left(18^{+}\right)$ \\
\hline Sachet $3^{\text {af }}$ & $0.51 \times 10^{2}(0)$ & $3.50 \times 10^{2}\left(18^{+}\right)$ & $1.70 \times 10^{2}\left(18^{+}\right)$ & $1.25 \times 10^{2}\left(18^{+}\right)$ & $6.5 \times 10^{1}\left(18^{+}\right)$ \\
\hline Sachet $4^{\mathrm{a}}$ & $0.85 \times 10^{2}(0)$ & $3.60 \times 10^{2}\left(18^{+}\right)$ & $2.60 \times 10^{2}\left(18^{+}\right)$ & $2.55 \times 10^{2}\left(18^{+}\right)$ & $1.10 \times 10^{2}(16)$ \\
\hline
\end{tabular}

Total bacteria count is expressed in colony forming units (CFU) while the coliform count is expressed in most probable number (MPN) as described in Cheesbrough (2000).

Legend: Samples with different alphabets are significantly different from one another using Duncan's Multiple Range Test at P $\leq 0.05$ i.e. Locations B1, W2 and W3 are

significantly different from locations B2 and W1. Locations B1, W1 and W2 are significantly different from location W3 while Locations B1, B2, W2 and W3 are significantly

different from Sachet 3 when compared for the amount of reductions recorded in mean population of bacteria in the water samples due to storage for ten days. 
Table 4: Physicochemical analysis of drinking water samples before (and after) storage for ten days when compared with Nigerian Institute of Standards set limits.

\begin{tabular}{|c|c|c|c|c|c|c|}
\hline $\begin{array}{l}\text { Water } \\
\text { samples }\end{array}$ & pH & Temp $\left({ }^{\circ} \mathrm{C}\right)$ & $\begin{array}{c}\text { Conductivity } \\
\left(\mu \mathrm{S} \mathrm{cm}^{-1}\right)\end{array}$ & $\begin{array}{c}\mathrm{Ca}^{2+} \\
(\mathrm{mg} / \mathrm{mL})\end{array}$ & $\begin{array}{c}\mathrm{Mg}^{2+} \\
(\mathrm{mg} / \mathrm{mL})\end{array}$ & $\begin{array}{l}\text { Chloride } \\
(\mathrm{mg} / \mathrm{mL})\end{array}$ \\
\hline \multirow[t]{2}{*}{ B1 } & 6.62 & 27.10 & 149.35 & 11.86 & 10.71 & 70.01 \\
\hline & $(7.26)$ & $(26.10)$ & (131.05) & $(37.20)$ & $(78.12)$ & (7.09) \\
\hline \multirow[t]{2}{*}{ B2 } & 6.76 & 27.70 & 161.20 & 9.62 & 8.64 & 23.04 \\
\hline & (7.54) & $(26.25)$ & $(126.45)$ & $(80.00)$ & (168.00) & (7.09) \\
\hline \multirow[t]{2}{*}{ W1 } & 6.98 & 27.80 & 229.00 & 14.43 & 12.96 & 46.09 \\
\hline & (7.93) & $(26.15)$ & $(326.50)$ & $(74.80)$ & (157.08) & (7.09) \\
\hline \multirow[t]{2}{*}{ W2 } & 7.59 & 27.30 & 345.00 & 0.02 & 0.04 & 37.22 \\
\hline & $(7.75)$ & $(26.20)$ & $(212.50)$ & $(34.00)$ & (71.40) & (7.09) \\
\hline \multirow[t]{2}{*}{ W3 } & 6.99 & 27.30 & 169.70 & 6.16 & 5.53 & 35.45 \\
\hline & $(6.76)$ & $(26.05)$ & $(271.00)$ & (122.00) & $(256.20)$ & (18.43) \\
\hline \multirow[t]{2}{*}{ S1 } & 7.09 & 27.30 & 161.75 & 4.81 & 4.32 & 23.93 \\
\hline & $(7.65)$ & $(26.15)$ & $(156.70)$ & $(20.00)$ & $(42.00)$ & $(36.51)$ \\
\hline \multirow[t]{2}{*}{$\mathrm{S} 2$} & 6.72 & 27.00 & 76.05 & 5.13 & 5.25 & 17.73 \\
\hline & (7.74) & $(26.15)$ & $(80.75)$ & $(24.00)$ & $(50.40)$ & $(74.45)$ \\
\hline \multirow[t]{2}{*}{ S3 } & 6.30 & 26.70 & 106.90 & 4.81 & 4.32 & 8.86 \\
\hline & $(7.53)$ & $(26.10)$ & $(79.55)$ & $(33.20)$ & $(69.72)$ & (72.67) \\
\hline \multirow[t]{2}{*}{ S4 } & 6.70 & 27.30 & 141.30 & 0.06 & 0.86 & 26.59 \\
\hline & (7.15) & $(26.05)$ & $(181.20)$ & $(24.80)$ & $(52.08)$ & $(56.01)$ \\
\hline *NIS- & $6.5-8.5$ & Ambient & None & 150 & 0.20 & 250 \\
\hline \multirow{2}{*}{\multicolumn{7}{|c|}{ B1 = borehole water samples from Imedu Nla; B2 = borehole water samples from }} \\
\hline \multicolumn{4}{|c|}{$\begin{array}{l}\mathrm{B} 1=\text { borehole water samples from Imedu Nla; } \mathrm{B} 2=\text { borehole water samples from } \\
\mathrm{W} 1=\text { well water samples from Imedu Nla; } \mathrm{W} 2=\text { Well water samples from Mowe }\end{array}$} & & & \\
\hline \multicolumn{7}{|c|}{$\mathrm{W} 3=$ well water samples from Loburo; $\mathrm{S} 1=$ sachet water brand no. 1} \\
\hline \multicolumn{7}{|c|}{$\mathrm{S} 2=$ sachet water brand no. $2 ; \mathrm{S} 3=$ sachet water brand no. 3} \\
\hline \multicolumn{7}{|c|}{$\begin{array}{l}\text { S4 = sachet water brand no. 4; *NIS-NSDWQ: Nigerian Institute of Standards- Nigerian Standard for Drinking Water } \\
\text { Quality Assessment Limits }\end{array}$} \\
\hline
\end{tabular}

\section{DISCUSSION}

The results of the present study reveal the great risk of contamination of drinking water due to unavailability of municipal water supply in the study area. Table 1 shows that most of the untreated drinking water sources available to members of this community fail to meet the WHO standards for taste, odour and physical appearance. Taste and odour in drinking water is indicative of pollution either from microbes or chemical sources. A high level of turbidity is known to protect microorganisms from the effects of disinfection and can stimulate bacterial growth. The presence of particles recorded for the well water samples evaluated in the present study correlates well with the high bacterial load recorded for well water in this community.

All of the sachet water brands evaluated in this study failed to meet the compliance levels set by the National Agency for Food and Drug Administration (NAFDAC) for label requirements. However, the fact that all the sachet water brands evaluated met the WHO standards for physical appearance demonstrates the superior quality of the treated water sources when compared to the untreated borehole and well water sources. This observation also underlines the importance of the water vendors to the provision of potable drinking water in this community due to the absence of municipal water. 
Table 5: Frequency of occurrence of bacterial isolates found in the water samples.

\begin{tabular}{|c|c|c|c|c|c|c|c|c|c|c|c|}
\hline $\begin{array}{l}\text { Bacterial } \\
\text { isolates }\end{array}$ & 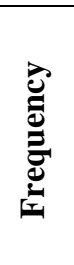 & 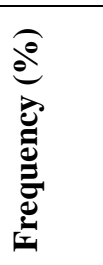 & 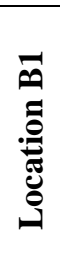 & 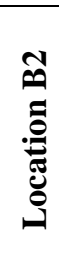 & 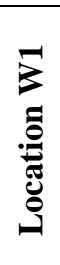 & 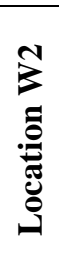 & 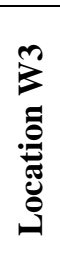 & 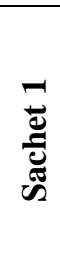 & 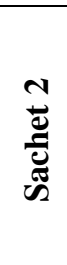 & 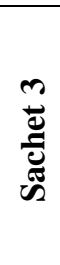 & 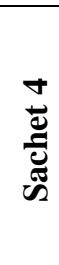 \\
\hline Escherichia coli & 2 & 4.08 & - & + & - & - & + & - & - & - & - \\
\hline Bacillus cereus & 6 & 12.24 & + & + & + & + & - & + & - & - & + \\
\hline Citrobacter freundil & 9 & 18.37 & + & + & + & + & + & + & + & + & + \\
\hline Salmonella typhymurium & 1 & 2.04 & - & - & - & - & - & - & - & - & + \\
\hline Pseudomonas aeruginosa & 4 & 8.16 & - & + & + & - & + & + & - & - & - \\
\hline Staphylococcus aureus & 5 & 10.20 & + & + & + & - & - & - & + & + & - \\
\hline Klebsiellapneumoniae & 2 & 4.08 & - & + & - & + & - & - & - & - & - \\
\hline Arizona spp. & 9 & 18.37 & + & + & + & + & + & + & + & + & + \\
\hline Proteus vulgaris & 9 & 18.37 & + & + & + & + & + & + & + & + & + \\
\hline Enterobacter aerogenes & 2 & 4.08 & - & + & - & - & + & - & - & - & - \\
\hline Total & 49 & 100 & 5 & 9 & 6 & 5 & 6 & 5 & 4 & 4 & 5 \\
\hline
\end{tabular}

B1 $=$ borehole water samples from Imedu Nla; B2 = borehole water samples from Mowe

$\mathrm{W} 1$ = well water samples from Imedu Nla; W2 = Well water samples from Mowe

$\mathrm{W} 3=$ well water samples from Loburo; S1 = sachet water brand no. 1

$\mathrm{S} 2=$ sachet water brand no. $2 ; \mathrm{S} 3=$ sachet water brand no. $3 ; \mathrm{S} 4=$ sachet water brand no. 4

The present study however reveals that none of the brands complied with the NAFDAC labelling regulations requiring food labelling to be informative and accurate (NIS, 2007). None of the brands examined in this study displayed such required information as batch number, manufacturing date, best before date and nutritional information even though all of the brands provided the producer's name and address including the NAFDAC number. Similar observations have been reported in various parts of Nigeria (Dada, 2009; Edema et al., 2011). The zero compliance to labelling requirements reported in different parts of Nigeria underscores enforcement issues with government regulations when compared to Tanzania showing a 54\% compliance rate in a similar study (Kassenga, 2007).

Physicochemical analysis of the water samples from boreholes and wells revealed that none of the samples met the quality assessment parameters of the Nigerian Industrial Standard (NIS) for $\mathrm{Ca}^{2+}, \mathrm{Mg}^{2+}$ and
$\mathrm{Cl}^{-}$. The values recorded in the present study exceeded the NIS set limits for these ions (NIS, 2007). The $\mathrm{pH}$ and temperature recorded for all the tested water samples however met the NIS set limits as shown in Table 3. Physicochemical analysis of the sachet water samples followed a similar pattern as the untreated and failed to meet the quality assessment parameters of the Nigerian Industrial Standard (NIS) for $\mathrm{Ca}^{2+}, \mathrm{Mg}^{2+}$ and $\mathrm{Cl}^{-}$. The values recorded in the present study were found to exceed or to fall significantly below the NIS set limits for these ions (NIS, 2007). By the end of the evaluation period of ten days, a significant increase in the amount of $\mathrm{Ca}^{2+}$ and $\mathrm{Mg}^{2+}$ ions was observed. Even though there was a slight increase in the $\mathrm{Cl}^{-}$ amounts for all the sachet water samples, the values were still significantly lower than the NIS requirement for treated water (Table 4).

Sobsey (2002) identified methods such as chlorination, iodine, filtering and solar disinfection as viable point-of-use or 
household level disinfection of drinking water. The present report shows that water storage for 2-7 days is another viable method that may be added to the repertoire of household level methods to alleviate the weak health infrastructure due to high numbers of fatalities for many preventable diseases such as diarrhoea directly traceable to poor water supply and sanitation and unhygienic living conditions in rural communities. Due to its inexpensiveness and effectiveness demonstrated in this study it is hoped that water storage will be embraced as a viable water treatment option in poor rural communities in Nigeria and elsewhere.

\section{REFERENCES}

Ademoroti CMA. 1996. Standard Methods for Water and Effluents Analysis Physicochemical Examination. University of Benin Press, Nigeria; 21-23.

Adikari Y, Yoshitani J. 2009. Global trends in water-related disasters: an insight for policymakers. In The United Nations World Water Assessment Programme Insights Series. UNESCO: Paris, France.

Alabi SA, Audu RA, Oyedeji KS, Mafe AG, Uhangho JE. 1998. Viral, bacterial and parasitic agents associated with infantile diarrhoea in Lagos. Nig. J. Med. Res., 2(1/2): 29-32.

APHA (American Public Health Association). 1998. Standard Methods for the Examination of Water and Wastewater (20 ${ }^{\text {th }}$ edn). Washington DC: USA; 23-54.

Cheesbrough M. 2000. District Laboratory Practice in Tropical Countries. (Part 2, $2^{\text {nd }}$ edn). Cambridge University Press: U.K; 22.

Clasen T, Schmidtz WP, Rabie T, Roberts I, Cairncross S. 2007. Interventions to improve water quality for preventing diarrhoea: systematic review and metaanalysis. BMJ., 334(7597): 755-756.

Dada AC. 2009. Sachet water phenomenon in nigeria: assessment of the Potential Health Impacts. African J. Microbiol. Res., 3: 15-21.
Edema MO, Atayese AO, Bankole MO. 2011. Pure water syndrome: bacteriological quality of sachet-packed drinking water sold in Nigeria. African Journal of Food Agriculture, Nutrition \& Development, 11(1): 4595-4608.

Egwari L, Aboaba OO. 2002. Environmental impact on the bacteriological quality of domestic water supplies in Lagos, Nigeria. Rev. Saude Publica, 36(4): 513520.

Eniola KIT, Olayemi AB, Awe S, Adegoke A, Osanoto IB, Abolade GO, Kayode-Isola TM. 2006. Effect of storage on bacteriological quality of well water. African Journal of Clinical and Experimental Microbiology, 7(1): 27-32.

Federal Ministry of Health of Nigeria. 1991. WHO/UNICEF/USAID/CCCD. Lagos: Nigerian Control of Diarrhea Diseases Programme, 1991-1995. Federal Ministry of Health, Lagos.

Fragio AG. 2005. The European response to the challenges of urban water supply and sanitation in the developing countries. Tribune, 2: 86-89.

Graham WK, Ashley M, Parker MT. 1984. Principles of Bacteriological Virology, Immunity. General Microbiological Immunity $\left(7^{\text {th }}\right.$ edn). Edward Arnold Publishers Ltd; 260-265.

Jimoh OD, Wojuola OA. 2009. Shallow aquifer resources in the federal capital territory of Nigeria. Water and Environ. J., 23: 41-45.

Kasenga GR. 2007. The health-related microbiological quality of bottled drinking water sold in Dar es Salaam, Tanzania. J. Water Health, 5(1): 179-185.

Khatri KB, Vairavamoorthy K. 2007. challenges for urban water supply and sanitation in the developing countries. Discussion Draft Paper for the Session on Urbanisation Delft UNESCO-IHE Netherlands, p.2-20.

Nigerian Industrial Standard. 2007. Nigerian standard for drinking water quality. standards organisation of Nigeria, Lagos 
\& Abuja, Nigeria. Accessed from http://www.unicef.org/nigeria/ng_publicat ions_Nigerian_Standard_for_Drinking_W ater_Quality.pdf on 15th June, 2012.

Olayemi AB, Awe S, Eniola KIT, Osanoto IB, Awe S, Eniola KIT, Osanoto IB, Adegoke A, Abolade GO. 2005. Effect of storage on bacteriological quality of borehole water. African Journal of Clinical and Experimental Microbiology, 6(3): 213218.

Olowe OA, Ojurongbe O, Opaleye OO, Adedosu OT, Olowe RA, Eniola KIT. 2005. Bacteriological quality of water samples in Oshogbo Metropolis. African Journal of Clinical Experimental Microbiology, 6(3): 219-222.

Onifade AK, Ilori RM. 2008. Microbiological analysis of sachet water vended in Ondo State, Nigeria. Environ. Res. J., 2(3): 107110.

Onweluzo JC, Akuagbazie CA. 2010. Assessment of the quality of bottled and sachet water sold in Nsukka town. Journal of Tropical Agric., Food Envir. and Ext., 9(2): 104-110.

Prescott LM, Harley JP, Klein DA. 1999. Water. Microbiology (4 ${ }^{\text {th }}$ edn.) McGraw Hill Co. Inc.: NY; 876-882.

Radojevic M, Bashkin VN. 2006. Practical Environmental Analysis ( $2^{\text {nd }}$ edn) RSC Publishing: U.K.; 147-170.

Raji MIO, Ibrahim YKE. 2011. Prevalence of waterborne infections in Northwest Nigeria: A retrospective study. J. Public Health and Epidemiology, 3(8): 382-385.
Sobsey M. 2002. Managing water in the home: accelerated health gains from improved water supply. World Health Organization, Geneva. Accessed from http://www.who.int/water_sanitation_heal th/dwq/wsh0207/en/index.html on 27th December, 2012.

The Red Cross, Crescent Societies. 2011. Nigeria: cholera outbreak. accessed from http://reliefweb.int/sites/reliefweb.int/files /resources/Full_Report_1817.pdf on 14th June, 2012.

Tortora GJ, Derrickson B. 2007. Principles of Anatomy and Physiology $\left(11^{\text {th }}\right.$ edn). John Wiley \& Sons, Inc. NJ: USA; 1036-1055.

WHO. 1995. Recommendations: Guidelines for Drinking Water Quality-Geneva ( $2^{\text {nd }}$ edn). Reprinted by Laxmand Chand Arya for All India Travellers Booksellers: Delhi; 1:47.

WHO/UNICEF. 2000. Global water supply and sanitation assessment 2000, Report WHO/UNICEF- Joint Monitoring Programme for Water Supply and Sanitation. WHO, Switzerland, 7-41.

WHO. 2004. Guidelines for Drinking Water Quality (3 ${ }^{\text {rd }}$ edn, Vol 1). WHO: Geneva; Switzerland.

WHO. 2006. WHO Guidelines for Drinking Water Quality (3 ${ }^{\text {rd }}$ edn). World Health Organization: Geneva.

World Bank. 2000. Federal Republic of Nigeria: Water Supply and Sanitation Interim Strategy Note. World Bank: Washington, DC. 